\title{
Mourning My Mother: An Exploration of the Complex Emotions Elicited by the Terminal Illness of an Estranged Parent
}

\author{
By Anne Bettina Pedersen
}

\begin{abstract}
In 2017, I learned that my estranged mother had been diagnosed with terminal cancer. This article explores the conflicting emotional responses I have had following the decision not to reconnect with my mother, not to provide care for her during her illness, and not to attend her funeral (when the time comes). This study combines my own creative explorations of child neglect, through autophenomenography, with examinations of autobiographical accounts of mother-daughter relationships and literature on family estrangement and the loss of a parent. I suggest that I already 'read' myself as a motherless daughter, and that caring, (re)mourning, and (re)grieving for my mother would entail reentering a dysfunctional dyad and opening up past wounds. There appear to be few resources to draw on regarding how to navigate this particular emotional terrain. This article does not intend to provide a prescriptive model for this type of loss, but rather aims at opening up for queer modes of grieving and mourning and suggests that, in some cases, the denial of care for an estranged parent translates into self-care and self-preservation.
\end{abstract}

\section{KEYWORDS}

Family estrangement, terminal illness, mourning, self-care, autophenomenography 


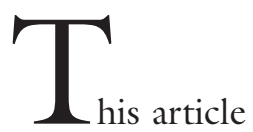

is my own personal exploration, through academic research and autobiographical writing, of the complex emotions I am experiencing after having learned that my estranged mother is dying of cancer. I am trying to navigate a chaotic emotional landscape by following my instincts and in general doing and feeling the opposite of what might be considered normative social behaviour. In this article, I intersperse parts of Survivor of the Toxic Womb (translated from Danish), a slam poem I wrote and performed in 2016, as well as material written specifically for this article, with writings grounded in research on, for example, family estrangement and the loss of a parent. This structure accentuates how my personal experience of estrangement from my mother and my responses to her illness entangle with my academic as well as my creative work. I am using autophenomenography, a method described by Nina Lykke in When death cuts apart: On affective difference, compassionate companionship and lesbian widowhood as the writing of autobiographical texts "[g]rounded in an understanding of writing as a method of inquiry" (Lykke 2018, 110). In Running Embodiment, Power and Vulnerability. Notes Toward a Feminist Phenomenology of Female Running, Jacquelyn Allen-Collinson explains that this method produces "rich, textured descriptions of first-person experience" (Allen-Collinson 2010, 285). By using autophenomenography, I become "both researcher and participant" (ibid., 286), as Allen-Collinson writes.

Except for the passages from my slam poem that I translated from Danish to English, I constructed the autobiographical segments specifically for this article. Survivor of the Toxic Womb appears in a shortened version, and I integrated one stanza into Ugly Feelings. Writing these segments for my article allowed me to explore and recall memories voluntarily and intentionally, instead of waiting for them to appear against my will. Although my recollection is, of course, subjective, and I have a general distrust of my memory, as I point out in my meditations on specific memories, I believe that in dealing with these memories in a creative manner and writing them down, I have captured an essence of events that have hugely impacted my life. I have paid specific attention to olfactory memories and have included smells to imbue the segments with a sensory dimension. Further, I have used recurring objects, phrases, and motifs, such as a shoe caught in an elevator, to create a cohesive narrative. The sources I engage with in the article inspired writings, and writings inspired me to pursue theoretical explorations, so my personal memories and my academic research fed off each other. The intent was to create a text where theory and autophenomenographical writing complement and accentuate each other.

The article reflects the messy thoughts and feelings I am experiencing at the moment and thus becomes an expression of my own process of grieving and mourning. In trying to find meaning in a situation I find absurd and confusing, I am reaching out, like a ravenous octopus, in multiple directions, grasping at words and concepts that might somehow illuminate my topic. I offer this text as a queer alternative to research papers and self-help books on the topic, which often focus on the experiences of patients or research subjects and tend to be governed by a professional distance to the topic. As Colin Murray Parkes explains in his foreword to the 2013 edition of Rebecca Abrams' When Parents Die: Learning to Live with the Loss of a Parent, "the best lessons about bereavement are those given to us by bereaved people themselves" (Abrams 2013, xi). Although some books, such as Fiona Marshall's Losing a Parent 
(2011) do briefly touch upon the grief experienced after the death of an estranged parent, most of these texts ignore the possibility that the estranged (adult) child might not want to follow the normative scripts regarding, for instance, the funeral. In Grief Works: Stories of Life, Death and Surviving (2017), Julia Samuel mentions that unhealthy relationships between parents and children can lead to complicated grief after the parent's death: "we may be relieved that it is the end of a relationship that has always been disappointing or hurtful. We may have complex feelings of love and hate, relief and guilt" (Samuel 2017, 84). Abrams also brings up the topic of complicated grief and suggests that "[ $[$ ] ometimes a parent may have 'died' for you but continued living, for example after a stroke or through chronic alcoholism, or perhaps through divorce or separation" (Abrams $2013,37)$. She explains that "you may have had to mourn for the loss of a parent before the death itself, and this can make it very hard to know precisely what you have lost after the death" (ibid., 61). Both texts acknowledge that grief is particularly complicated in cases of toxic relationships and/or estrangement but do not explore the topic in-depth. With this article, I am hoping to add to and open up for further and extensive explorations of the topic.

When doing research for this article, I found little information pertaining to the situation I am in and the decisions I have made regarding my mother's cancer and future death. Upon hearing of her illness, I had to decide whether I would feel the need for closure before her death (and what closure might entail), whether I would be able to provide care for her, and whether I would want to attend her funeral. According to Samuel, "having had the opportunity to say everything you need to say to your parent is a vital comfort before and after their death" (Samuel 2017, 89). I understand and feel the need for some kind of closure, but any form of contact with my mother may lead to further trauma. Instead, I write this article.

Abrams lists the practical tasks associated with the organisation of a funeral, which "marks the passing of someone who has been precious to you, who has affected you, without whom you would not be as you are" (Abrams 2013, 24), and Marshall stresses that " $[\mathrm{t}]$ he funeral is an important part of grieving" (Marshall 2011, 43). Since I have chosen to extend our estrangement and not reestablish contact with my mother, and not take part in the funeral arrangements or the funeral, I will have to figure out if I can mark her death outside of the normative social script and opt for a queer mode of mourning instead. No matter what feelings I harbour for my mother, I cannot deny that she has made an impact on my life, and it might be necessary to perform some sort of ritual to acknowledge the (lack of a) relationship. I agree with Abrams when she writes that "[w]e do not grieve by a rule book" (Abrams 2013, 10), and I do not aim at providing a schematics. Instead, I hope to encourage others in situations similar to mine to remain critical of advice that does not take into account the complexities of family estrangement and to seek out alternative modes of grieving and mourning that challenge taboos and normative practices. I am indebted to Nina Lykke and her article on Queer Widowhood (2016), as it 1) inspired me to use autobiographical writing to examine the topics of child neglect and family estrangement by using my own personal situation as a lens and 2) helped me structure my paper by foregrounding my own experience and by allowing for segments of varied lengths.

\section{Telephone Terror}

The first time my mother told me she had terminal cancer, I was about eleven years old. I lived with my father and saw my mother sometimes on weekends. As far as I remember, she called me, drunk, in the 
middle of the night, and told me she was dying. She had a habit of calling my father's house at night, when she had been drinking, and making announcements that, if they were true, would have been life-altering for me (such as the time she lied and told me she and my dad were getting remarried). I blindly believed her over and over again, because, since I was quite young, she had offered me a reality governed by her - a reality that was so radically different from that of any of my friends, and a reality I believed in because, like so many other children of addicts, I was fiercely loyal to her and only later found out that she manipulated me (I still often distrust my own memory). When I think about this specific call, I picture myself standing in the living room next to the dark chocolate-coloured sofa or sitting on the oak coffee table, my fingers tracing the dents and scratches in the wood. The room is dark save for the rectangular squares of light cast on the floor by the street lamps outside the window. I remember crying and being terrified that my mother would be in pain, and that I would lose her to cancer. Even though she had neglected me and had often left me in vulnerable situations, I still wanted and believed we could have a healthy relationship. My mother never mentioned the cancer again. I do not know why she told me she had cancer. I do not know if she even remembers. I never forgot. Whenever the phone rings, I stare at it as if it were a bomb (my mother's number once again nuking my life).

The second time my mother told me she had terminal cancer, she told me through my father. I was in my late thirties. I had not spoken to my mother for three or four years. My sister ${ }^{1}$ and I had both conveyed to our mother that she was not to contact us. We both experienced anxiety at the thought of picking up the phone and hearing our mother's voice on the other end. My mother called my sister directly and told her she was sick, but my mother then phoned my father and asked him to be present, when she called me, so that he would be there to comfort me. Before she had a chance to call me, I wrote her a letter, asking her to respect my wish not to have any kind of contact with her and to leave my sister alone. I did not write my address on the envelope. I wanted to place between us an impenetrable wall of ice to protect my sister, my daughter, and myself from a person who was always transgressing boundaries. Instead of experiencing sadness, because my mother was sick, my response was to become angry that she had violated our wish not to have any kind of contact with her. Her cancer did not cancel out past transgressions, neglect, and toxic behaviour. Her cancer did not suddenly make me want to return to my role as my mother's caregiver. I have no care left to give her.

At first, I did not wholly believe that my mother was sick. A year and a half after my mother announced that she was dying (again), I am still not completely convinced that she is sick, although other family members talk about my mother's cancer. Finding out the specifics of her illness would entail going with my mother to a doctor's appointment and having the doctor explain the diagnosis and prognosis to me. It would entail reestablishing contact with her and reentering a toxic relationship, in which the roles of parent and child have been reversed; it would entail that I once again mother my mother. Instead, I have chosen to focus on caring for myself and for my daughter.

In her blog post on self-care, Selfcare as Warfare (2014b), Sarah Ahmed draws on Audre Lorde's idea in A Burst of Light (1988) of self-care and survival as radical acts, for instance when performed by black women navigating power structures that devalue their lives. To Lorde, self-care is an essential part of self-preservation. I am, of course, aware that as a white, European woman I have specific privileges in life, and 
that I have to be careful and respectful when utilising Lorde's and Ahmed's concepts. Ahmed's statement that "[s]ome have to look after themselves because [they] are not looked after: their being is not cared for, supported, protected" (Ahmed 2014b) resonates with me and reminds me how my mother taught me that although I was a child, my safety and wellbeing were not a priority. When I prioritise myself over my mother, I am insisting that my life has value and practising a form of self-care that echoes Ahmed's idea of selfcare as the act of putting back together that which has been shattered. Self-care means denying my mother the care that I am sure she needs, and choosing not to expose myself to potentially re-traumatising experiences. As part of my self-care regimen, I attend a small, local support group where I talk to other adult children who have chosen to estrange from their parents. I also speak openly about and against the taboo of family estrangement and my decisions regarding my mother's illness and eventual death, and I have chosen to engage with the topic through writing, which I benefit from in an academic, creative, as well as therapeutic sense.

In Missing family: the adult child's experience of parental estrangement (2017), Kylie Agllias asserts that the phenomenon of family estrangement is receiving more interest from scholars, the media, and online in the form of websites and support groups. However, the complex nature of family estrangement is often not apparent, and "stigmatising ideologies" (ibid.) appear to govern the discourse. Further, research done on the topic often focuses on the experience of the individual who has been estranged, whom Agllias refers to as the estrangee, instead of the individual who has chosen to cut off contact with a family member (the estranger) (Agllias 2017, 60). Thus, most literature on the topic accounts for the emotional damage done to a parent whose child has chosen to estrange them- selves from their parent. As Agllias explains, these texts generally "focus on prevalence, causation, risk factors and participant explanations for relationship breakdown" (ibid., 59). According to Agllias, research done on family estrangement is characterised by a "knowledge gap" (ibid., 60), and an overrepresentation of the experiences of the estrangee and that person's feelings of "being rejected, ostracised or excluded" (ibid.). In my personal experience, and through my talks with other estrangers, among my close friends, online, and in my support group, disengaging with a parental figure (or both parents) becomes an empowering act of self-care and self-preservation; for some of us, choosing to estrange from a parent represents the first time we have actively made the decision to acknowledge and prioritise our own physical and mental health, instead of constantly focusing on providing emotional care for a neglectful parent.

\section{CAnnot Be Simone de Beauvoir}

I cannot be Simone de Beauvoir, caring for her mother in A Very Easy Death (1965). I want, I need to keep my mother's illness and suffering at a distance. I cannot sit vigil by her bed, as she expires. I do not want the world "to shrink to the size of [her] room" (de Beauvoir 1965, 73), as de Beauvoir's world closed in around her in her mother's hospital room. De Beauvoir writes that " $[\mathrm{m}] \mathrm{y}$ real life took place at her side, and it had only one aim - protecting her" (ibid.); I insist on having my own life and never again being my mother's champion. Her mother's perfume, a cloying cloud, "sweetish and sickening" (ibid., 72), brings back memories of my own mother's favourite scent, MUSK Oil No 6, and I fear suffocating on that smell in her room/ womb/wound, in a tight, deadly, empty embrace, as her cancer claims the both of us. 


\section{Ugly Feelings}

My mother once told me that my anger was preventing us from having a good relationship (whatever 'good' means). I felt ashamed of my anger and ashamed of not being able to reply to her "I love you" with an "I love you, too" and to her "I miss you" with an "I miss you, too", of not showing the appropriate (according to her standards) amount of gratitude, when she presented me with gifts, and of not favouring her over all the other people in my life. I felt ashamed because I could not perform the role of 'loving daughter' without being obviously insincere. At age eight, I lay awake all night, crying, worrying about her, when she was out partying, like a teenager (I must have felt love for her then, love mixed with a sense of fierce loyalty). I have now embraced my anger, removed my mother from my life (but not my inner life), and realised that my anger is a product of my life experiences - my anger testifies that I did not imagine the neglect, that my feelings are valid, and that how she treated me should not be normalised or forgotten. I have come to love the night now, and I fill it with deep, seemingly dreamless sleep.

I have other ugly feelings, too, when it comes to my mother, and a list of them looks almost like the contents page of Sianne Ngai's Ugly Feelings from 2005. Except, I don't envy my mother. The word 'petty' comes to mind, when I think of how I act when I am around my mother. Or acted. I am no longer around her. Her voice irritates me. The way she mispronounces words. How she is oblivious to sexual innuendo (like when she said something that could be misunderstood as "The cats kept sniffing my vagina") and never gets a joke. I pride myself on being the funny daughter of an unfunny mother, on not being like her.

In Ugly Feelings, Ngai refers to disgust as "this ugly feeling par excellence" (Ngai 2005,334 ), and she attaches the adjectives "urgent and specific" (ibid., 337) to this feeling. I understand disgust as something unwanted that imposes itself on me; it demands immediate attention and a response, a head in the toilet or dry heaving over the sink. Every day (for more than twenty years now), a memory revisits me. This memory does not ask my consent but invites itself in, like a chatty neighbour with no sense of personal boundaries. I never know when the memory will appear - it favours sneak attacks. It is my most vivid memory of my mother and also the ugliest. This memory comes equipped with pungent smells and aims to disgust.

\section{Haunted/A STENCH}

Daily, I am haunted by the sight of your naked body. Wearing only a bathrobe, the belt untied, you open the door. As you stand there swaying, drunk, your pubic hair and breasts exposed, a naked man sits on the couch in the dark living room, guarding a table filled with empty bottles. A stench of boozy sex mixed with cigarette smoke hangs in the air like a thick, sickly cloud. I get a quick glimpse of two pathetic, sad addicts, who, in-between sips of lukewarm beer, thrust their bodies together, as they sob, simultaneously, "My kids don't wanna see me". My words might kill you, so I slap you instead. It's the only time I've ever hit you. On my way home, I savour the stinging redness of my hand.

\section{Dutiful/Disobedient Daughter}

As Susan Forward points out in Mothers Who Can't Love: A Healing Guide for Daughters (2013, 243), in most cases, adult children have carefully considered the decision to estrange from a parent, and it is often a slow and gradual progress. In Forward's opinion, when children have exhausted all other options (i.e. when they realise the relationship will always be destructive and toxic), they must focus on 
their own well-being (ibid., 244). Agllias's study backs this up and explains that many estrangers view cutting off contact as "the only avenue to personal growth, healing and happiness" (Agllias 2017, 64). There are, however, consequences to taking this step, as estrangers often feel guilty for having prioritised themselves and for breaking the taboo of criticising the institution of motherhood and, as Forward puts it, "for challenging the status quo, for taking an action that shakes the foundation of their concept of family, for daring to do what's best for them instead of continuing to sacrifice themselves to other people's expectations" (Forward 2013, 247).

I would add to this that not only do these estrangers challenge their own ideas of family but the heteronormative ideal of family that governs our society. In my case, I might be viewed as having rejected the role of the 'dutiful daughter', who as an adult gives back the care (supposedly) provided in childhood by the mother. Instead, I become a 'disobedient' daughter, in that I speak up about my mother's neglect and expose our relationship as toxic, and thus I challenge the heteronormative idea of the mother as a natural primary caregiver and as the parent who successfully prepares the daughter for her own potential motherhood.

As Forward explains, "Most societies glorify mothers, as if the mere act of giving birth makes them inherently capable of love, protection, and kindness" (ibid., 14). This "mother myth" (ibid.) provides a shield for "unloving mothers" (ibid.) to hide behind and makes children question the validity of and feel guilty about their own feelings. Their loyalty towards their unloving mothers might also cause them to go to great lengths to help their mothers keep up the appearance of a normal, healthy family. As Louise M. Wisechild explains in The Mother I Carry: A Memoir of Healing from Emotional Abuse (2014), "[a]s daughters we learned most of all that other people's opinions and needs mattered more than our own" (Wisechild 2014, 8). Thus, telling our stories and prioritising our own mental and physical health become radical acts of self-care.

The first time I misbehaved in public as a disobedient and disloyal daughter to my mother was when I performed "Survivor of the Toxic Womb" at a poetry slam in 2016. I put on black knee-high boots, a vintage fire engine red miniskirt (bought at a street market in Paris in the late 1990s), and I exorcised my mother from my body and myself from her body on stage. I could never say those words to her face, because the fear that my words ("This is what you did to me") might cause her to commit suicide still lingers. In the past, I wrapped my fragile mother in cotton wool and protected her life with my silence. I believed that my words were somehow magical: the right words could make her stop drinking, and the wrong words could break her heart and kill her (mustn't hurt mother dear oh dear). Agllias explains that "the creation of new expectations and rituals" (Agllias 2017 , 64) become a part of the healing process after having initiated an estrangement. I argue that this extends to the (impending) death of an estranged parent. In The Cultural Politics of Emotion (2014a), Sara Ahmed writes about queer feelings that "they may embrace a sense of discomfort, a lack of ease with the available scripts for living and loving, along with an excitement in the face of uncertainty of where the discomfort may take us" (Ahmed $2014 a, 155)$. I can choose to view the complex situation I am in as an opportunity to invent my own script, my own rituals of mourning my mother (I have already previously reframed Mother's Day as “Toxic Womb Day", a day where I celebrate surviving my mother's neglect).

\section{Post-Mortem Excision}

I imagine myself visiting my mother's grave 
a few days after her funeral. It is early spring. I am wearing my navy blue Ganni wool coat. I have finally gotten around to sewing back on the two buttons that have fallen off. I feel warm and snug and safe. I stare at the grave, and I want to feel. I want to feel so badly. I start reading my slam poem next to her grave as part of my own personal funerary ritual. In this way, I can perhaps properly excise her from me.

\section{Survivor of the Toxic Womb}

You are the woman who gave birth to me. You monologue constantly, caught up in your own problems, all your AA bullshit. Always unavailable, always spouting trivialities, going on about your furniture and your garden. Nice things. Safe things. Your mouth a chimney, spitting smoke and hot air. You bring with you chaos, neglected kids, and dead pets, rotting at the bottom of their cages. Beer and wine replaced by big, warm cups of self-pity and bleating lamentations. Alcoholic mother: the gift that keeps on giving.

I am forever drowning in your amniotic fluids, desperate for one, single, elusive bubble of air. I struggle and struggle and write and write my own story as mother, away, away from you, into the sunset, over the rainbow, happily ever after.

I imagine being back in your womb. Your fluids, stale water, stored inside me my entire life, embittered, fetid, infecting my thoughts, my flesh. I gnaw through the umbilical cord and worm my way out of your opening, while I scratch and claw at your insides. I am aborting myself from your toxic womb.

In a different scenario, I birth myself by tearing and biting my way through amnion and chorion, the fetal membranes, gnawing my way up, up, up, through you, past your heart, filled with love letters that say "Me, me, me!" gnawing my way from uterus to chest, where I break out, like an alien, creating a phenomenal fountain of flesh, blood, bones. Triumphant and exhausted, I rest on your chest. I have killed you, mother-monster. I am newly born, unborn by you.

\section{A Mother Always Dying, Already DeAD}

I seem to have spent much of my childhood in the hospital, visiting my mother. My father would take me to see her, both before and after their divorce. Once, my shoe got caught in the elevator somehow. That is the only distinct memory I have of these visits. The white walls and hospital smells were the same every time, as was my mother's mysterious ailment - something wrong with her stomach (she was always sick to her stomach). I wonder if the walls were actually white.

I think I have always associated my mother with disease and dying. Ask me to associate my mother with a specific sound, and I think of the sound of her vomiting in the bathroom (stomach flu, hangover, anxiety?). I think that when I was pregnant and vomited for seven months, I was trying to expel my mother from my body, rid myself of the mother wound she passed on to me, so as not to pass it on to my own child. My mother to me has become a poison from which I must protect my daughter. There will be no visiting grandmother in the hospital, no more shoes stuck in the elevator.

My mother often said she suffered from PID (pelvic inflammatory disease), which she was terrified I would also get at some point. She always projected her own illnesses onto me and claimed that we were so very similar. I found the thought of being like her in any way frightening. My mother also told me that she had some sort of problem with her stomach, when she was pregnant with me. The doctors were operating on her and were surprised to discover me, nestled inside her. I was lucky to be alive, she told me. I could have died inside her. Maybe my mother contaminated me 
with her sickness before I was even born and maybe she wore her mother wound on her body as a dark, wide scar that ran from below her belly button to her pubic bone. Sometimes, doctors would reopen the scar, so that they could fix her again; perhaps that is why she was in the hospital so often (she was sick to her stomach).

My mother also almost drowned once, when her car somehow ended up in a river. She would tell me this story often. I do not think she realised how, through her storytelling, she was setting herself up to be always on the brink of death, in my eyes. In my mind, she is always in the car, in the water, trying to get out, brought back and forth towards the death moment, like Kelly Kelleher in Joyce Carol Oates's Black Water (1993), which was loosely based on the 1969 death of Mary Jo Kopeche. In the novel, Oates kills off Kelly and resurrects her again numerous times - for instance, on one page, "the black water filled her lungs, and she died" (Oates 1993, 103), and then six pages later, she dies again. In my mother's memories, passed on to me, she is still floating in the water. I wonder what my life would have been like, if she had died back then, before I found out she could not mother me. I fear that I will be stuck with her in that car, in a sort of liminal state, until the day she expires. We have been forever balancing on the edge of something too fragile, and I long for firm ground beneath my feet.

I remember being in a car crash with my mother at some point, when I was a child, near one of the cemeteries in my hometown. Someone else was in the car, too. I wonder who it was. I also remember that my mother and I were once held hostage by her next-door neighbour, who was obsessed with her. He had a shotgun. He said he would shoot my father if my mother did not stop him from visiting us. I do not trust this memory, because it seems too absurd. It seems like a traumatising event. It seems like the police should have been there. It seems like something we should have discussed afterwards. Like something that should have somehow been processed. Instead, the experience just became a part of the collection of stories of my mother's narrowly escaping death. Like when my mother's blood alcohol level was so high, the medical emergency technicians were amazed she was still alive (my mother boasted about this to me, as if it were an accomplishment to be proud of).

My grandmother has told me of my mother's failed suicide attempts. Booze and pills. I wonder where I was while my mother was trying to kill herself. Maybe she went to the hospital afterwards, and I visited her. Maybe my shoe got stuck in the elevator. Maybe she called it pelvic inflammatory disease, but she actually tried to end her own life.

Maybe she tried to cut me out of her stomach with a knife, and that is why she has that scar. Maybe I really am lucky to be alive. Maybe she knew she would neglect me. Anything is possible; nothing is too outrageous or absurd, it seems. I mean, who lies about having cancer?

Stories are powerful, and my mother's tales of conquering death again and again made me always anticipate her death and fear for her life. When she went out drinking at night, and left me at home alone with my cat, Garfield, I never worried about myself; I worried that my mother would die. I worried that death would finally catch up with her. Maybe I already started distancing myself from her back then and prepared to be a motherless daughter. Maybe I already was and am a motherless daughter. Maybe that is why, upon learning that my mother is once again dying, I often feel nothing. Or I feel confused because I know that people are supposed to feel sad, when their mother is dying. Perhaps I have read her as dying/dead for over three decades now. Perhaps she taught me, through her stories, to read her that way. 


\section{AM NOT A MONSTER (I SWEAR)}

When I think about my mother's eventual death, and I feel numb, I feel like her neglect has turned me into a monster. And then I think about the people I have lost so far and remember mourning - my paternal grandmother, Karen, two friends (Julie at age nine, Camilla at age twenty-nine), and my paternal grandfather, Aksel, who died a month ago, on Halloween. I take a break from this paper and cry in the shower, and I feel less monstrous.

\section{Clapback}

I get provoked when I read books about how to cope with the death of a parent. When Fiona Marshall writes, "If you can't be sad at such a time [when your parent is dying], when can you?" I act like a child and comment "That's not how I feel!" and add a snide "Oh, really?" I clap back, I snap back, I feel excluded and weird, an anomaly. At the same time, I know and respect that authors have written these books to provide helpful advice to mourners and not to piss me off.

\section{"I'Ll Have What She's Having"}

I want the grief of daughters who felt loved by their dead mothers. I want to find letters my mother wrote me and weep with happy-sad tears at the trivialities described and her desire to connect. I have always envied others their loving mothers.

\section{HeAvy Burden}

I think of parents as having a sacred duty to provide their children with a huge backpack filled with stuff that will make it easier for them to navigate through life - a sort of survival kit. I blame my mother for raiding my backpack and leaving me with an empty survival kit and teaching me only what not to do - most of the lessons learned are painfully obvious, such as "Don't leave your child with strangers, while you go out drinking" or "Don't spend all your money on cigarettes and booze, so that your child will have to wipe her ass on softened pieces of coffee filters". I sometimes forget to look at all the valuable things my father put in my backpack, and I need to remind myself that I base many of my ideas of motherhood on heteronormative views and writings on parenthood and the premise that mothers should be the primary caregivers. The mother-daughter dyad often appears in/on cultural artefacts as symbolic of an idealised relationship, as a bond stronger than all others. I realise that I have internalised these views and draw on them in this article, at the same time that I desire to challenge them.

\section{The Mother Wound}

When evaluating the legacy my mother has left me with, I keep returning to the concept of the "mother wound", which is explored by, for instance, Forward in Mothers Who Can't Love. The term refers to the emotional damage toxic or narcissistic mothers inflict on their children, and which those children may in turn pass on to their own children. As Forward explains, many of her clients "carry with them a legacy of pain, fear, and turmoil because of the profound emotional wounds inflicted by their mothers" (Forward 2013, 2). The pain of realising that my longing for a loving mother and the healing of my own mother wound will never be fulfilled is, for me, personally, the greatest sorrow of my life. I am reminded of Adrienne Rich's Of Woman Born: Motherhood as Experience and Institution (1986) and her description of how many adult daughters still yearn for their mothers (or $a$ mother), how they are "still longing for a woman's nurture, tenderness, and approval, a woman's power exerted in our defense, a woman's smell and touch and voice, a woman's strong arms around us in moments of fear and pain" (Rich 
$1986,224)$. I have one very distinct memory related to my mother wound, and that memory is characterised by a deep and fundamental yearning. I keep returning to this memory of lying next to my mother in bed and being too afraid to ask her for a hug, for intimacy, because I fear that she would deny me the love I so desperately desire. I am always either stuck in the car, drowning with my mother (who is sick to her stomach), or forever reaching for love that I dare not ask for.

\section{Wounded}

My small body next to yours in the dark. Your breath a symphony of sleep. My hand keeps reaching for you. Never finds you. If I pick up some beer for you at the grocery store tomorrow, perhaps then you will love me.

\section{THe VoID}

In A Very Easy Death, de Beauvoir describes the mother wound (without using this specific term) as an act of cannibalism: her mother "flung herself into the only other course that was available to her - that of feeding upon the young lives that were in her care" (de Beauvoir 1965, 38). Instead of giving her children sustenance, the unloving/abusive mother draws sustenance from her children: she is the monster mother/mother monster as vampire. The image of the mother as a vampire and a cannibal alludes to a blurring of boundaries between the bodies of mother and child in toxic relationships. When feeding upon her daughter, the mother is also at the same time feeding upon herself, as the two have formed an unhealthy and all-consuming dyad. Wisechild describes her mother's dependence on her daughter for the fulfilment of emotional needs as suffocating: "Her needs felt like oil pouring out from her hands and chest. I forgot what I had been playing because I had to make Mom- my feel better. But then it was hard to breathe. And I began to see that I was going to have to choose, her or me" (Wisechild 2014, 45). Based on my own experiences as well as conversations with other daughters of neglectful mothers, this shift away from the needs of the daughter to the needs of the mother is quite common in toxic mother-daughter relationships. Forward even dedicates an entire chapter to "Mothers Who Need Mothering". As she explains, daughters who mother their mothers have "essentially been robbed of the chance to have a healthy childhood" (Forward 2013, 88). Together, the lost childhood and the lack of a caring mother figure create a void or, as Forward puts it, "a gaping mother wound" (ibid., 4).

When a mother leaves a gap in her daughter's life instead of fulfilling that child's emotional needs, she comes to signify an absence that may affect the daughter's ability to grieve her mother's death. In a sense, the mother becomes ungrievable. Or, rather, grief may attach itself to the absence of a nurturing mother and not to the death of the neglectful mother. In Frames of War: When Is Life Grievable? (2016), Judith Butler defines "[u]ngrievable lives" (Butler 2016, xix) as "those that cannot be lost, and cannot be destroyed, because they already inhabit a lost and destroyed zone" (ibid.). My mother does not live in a war zone, but to me, precarity has still characterised her life - her alcoholism and health problems have kept her off the job market for more than three decades - and, since my childhood, I have viewed her as inhabiting a liminal space between life and death.

I do not intend to ascribe no value to my mother's life or dehumanise her; I am merely trying to explain how her social status, her neglect, and her many brushes with death have affected how I read her. I also distinguish between my mother as an individual human being, with her own life and challenges, and my mother as my biological 
mother, who has not cared for me. Butler writes that "specific lives cannot be apprehended as injured or lost if they are not at first apprehended as living" (ibid., 1). My argument is that it may be difficult for me to view my mother's future death as a loss, since she has not and does not fulfil the role of a mother in my life. As Butler explains, " $[\mathrm{t}]$ he epistemological capacity to apprehend a life is partially dependent on that life being produced according to norms that qualify it as a life or, indeed, as part of life" (ibid., 3). I am aware that the mother myth places mothers on a pedestal and that, as Forward puts it, it is "a fantasy to believe that the role of mother is automatically synonymous with healthy love" (Forward 2013, 13), yet that powerful myth does accentuate my feeling of having a void in my life because of my mother's neglect. I am critical of the romanticised image of motherhood but also aware of how heteronormative representations of motherhood have shaped my life, and that I may be reading my mother as ungrievable and already lost because, as a mother figure, she does not live up to a normalised and idealised image of motherhood. ${ }^{2}$

\section{What Happens After?}

In Queer Widowhood, Nina Lykke explains that "[a] funeral is a very intimate thing" (Lykke 2016, 93). Going to my mother's funeral will not be an option for me, as I do not wish to return to an intimate relationship with my mother in any kind of way. I also realise that my own funerary ritual for my mother needs to be intimate in the sense that it needs to be private; I need to feel safe from potentially condemning family members, who might want me to keep up appearances for the sake of the family. For my own sake, I feel that I must reject the funerary rituals offered, as they are unsuited for my specific needs. I am afraid that I will be met, at the funeral, with silences regarding the trauma my mother inflicted upon her children. I am afraid of people's offering me their condolences. How could I possibly respond to someone expressing how sorry they are for my loss? I would either have to thank them, smile politely, and be completely dishonest, or I would have to be honest and tell them that my real loss is that I never actually had a mother. I would then be disrupting the ritual. I am taking a risk that involves the potential for people's misinterpreting my act of self-care as evidence of my being selfish.

What would that act of honesty and disruption cost me? What are the consequences of being the child who does not show up for their mother's funeral? People will notice my absence at her funeral and might view it as my outing her as a neglectful parent. I am afraid of being judged as being heartless, unfeeling. My insistence on self-care becomes a threat to the concept of the family, understood as a heteronormative space where members perform the roles they have been ascribed because of their gender. In The Cultural Politics of Emotion, Ahmed explains that "[n]ormativity is comfortable for those who can inhabit it" (Ahmed 2014a, 2). Having realised how unhealthy my relationship with my mother was, I can no longer uphold the appearance of normalcy - I cannot pretend that we have ever been a 'normal' family. My failure to reproduce the script that governs what happens at funerals and who attends will probably cause great discomfort and sadness for those of my family members who attend my mother's funeral. I do not think of it as a vengeful or spiteful act, but as an act of self-preservation.

There is a horrible guilt in waiting for someone to die, in wanting not to be afraid of the telephone anymore. I feel as if de Beauvoir is trying to guilt-trip me when she writes about terminally ill patients who have no loved ones to care for them at the end of their lives, and who have " $[\mathrm{n}] \mathrm{o}$ hand on the forehead when terror seizes them; no sedative as soon as pain begins to tear 
them; no lying prattle to fill the silence of the void" (de Beauvoir 1965, 94). I do not want my mother to suffer, but I cannot be the one to offer her solace. In writing this paper, a few answers have appeared as well as further questions to evaluate. Should I feel guilty about dehumanising my mother and turning her into a topic to explore in a paper? Is that even what I am doing? In a sense, my mother has always been a void in my life, a need never fulfilled, a shadow image of a loving mother figure. I think my next step of this process will be to venture further down the rabbit hole/black hole/void that is my relationship with my mother and try to find more answers and questions.

\section{NOTES}

1. I am twelve years older than my sister. We do not have the same father and have never lived together. We each have our own experience of living with our mother; I lived with my mother when her alcohol abuse was at its peak, and my sister lived with her after she had become sober. Ultimately, my mother's continued destructive patterns of behaviour made it impossible for either of us to have her in our lives.

2. An in-depth exploration of Butler's concepts of precarity and grievability in relation to my estrangement from my mother is beyond the scope of this article, but I do intend to explore them further.

\section{REFERENCES}

- Abrams, R. 2013. When Parents Die: Learning to Live with the Loss of a Parent. Third edition. Oxon: Routledge.

- Agllias, K. 2017. Missing family: the adult child's experience of parental estrangement. Journal of $\mathrm{So}^{-}$ cial Work Practice. 32(1), 59-72. DOI:

https://doi.org/10.1080/02650533.2017.1326 471

- Ahmed, S. 2014a. The Cultural Politics of Emotion. Second edition. Edinburgh: Edinburg University Press.

- Ahmed, S. 2014b. Selfcare as Warfare. Feministkilljoys. [online]. [Accessed on March 13, 2019]. Available at:

https://feministkilljoys.com/2014/08/25/selfcare-as-warfare/

- Allen-Collinson, J. 2010. Running Embodiment, Power and Vulnerability: Notes Toward a Feminist Phenomenology of Female Running. In: Kennedy E. \& Markula, P. eds. Women and Exercise: The Body, Health and Consumerism. New York: Routledge, 280-298.

- de Beauvoir, S. 1965. A Very Easy Death. New York: Pantheon Books.

- Butler, J. 2016. Frames of War: When Is Life Grievable? London: Verso.

. Forward, S. 2013. Mothers Who Can't Love: A Healing Guide for Daughters. New York: HarperCollins Publishers.

- Lykke, N. 2016. Queer Widowhood. Lambda Nordica. (4), 85-111.

- Lykke, N. 2018. When death cuts apart: On affective difference, compassionate companionship and lesbian widowhood. In: Juvonen, T. \& Kohlemainen M. eds. Affective Inequalities in Intimate Relationships. New York: London, 109-125.

- Marshall, F. 2011. Losing a Parent. Second edition. London: Sheldon Press.

- Ngai, S. 2005. Ugly Feelings. Cambridge, MA: Harvard University Press.

- Oates, J. 1993. Black Water. New York: Plume. - Rich, A. 1986. Of Woman Born: Motherhood as Experience and Institution. New York: W. W. Norton \& Company.

- Samuel, J. 2017. Grief Works: Stories of Life, Death and Surviving. London: Penguin Life.

- Wisechild, L. 2014. The Mother I Carry: A Memoir of Healing from Emotional Abuse. Second edition. Venado Press. 